\title{
Analisis Sistem Pengendalian Internal Siklus Penjualan Pada PT. Hasjrat Abadi Cabang Manado dan PT. Bosowa Cabang Manado
}

\section{INDAH EUNIKE KAKUNSI ${ }^{1}$, VENTJE ILAT ${ }^{2}$, HENDRIK MANOSSOH $^{3}$}

\author{
${ }^{1,2,3}$ Program Magister Akuntansi, Fakultas Ekonomi dan Bisnis Universitas Sam Ratulangi \\ email: indaheunike55@gmail.com ${ }^{1}$, ventje.ilat@yahoo.com², hendrik_manossoh@yahoo.com ${ }^{3}$
}

\begin{abstract}
This study aims to analyze the internal control system of the sales cycle at a distributor company in Manado by using COSO internal control. This is a qualitative research with an exploratory approach. Data were obtained by in-depth interviews, observation and documentation study. The results showed that the sales cycle at PT Hasjrat Abadi Manado Branch and PT. Bosowa Group Manado has been carried out according to companydetermined procedures, but internal control procedures still need to be improved so that there are no more irregularities in the credit sales process in the two companies that were the object of the study. Internal cycle control at PT. Hasjrat Abadi Manado Branch and Bosowa Group are in accordance and implemented based on the COSO (The Committee of Sponsoring Organizations Of Treadway Commission) internal control guidelines which include the principles of control environment, risk analysis, control activities, information and communication, as well as monitoring or monitoring activities. However, in the implementation of internal control in the sales cycle in accordance with the COSO guidelines still found several obstacles in each of these principles. Control Activity has the largest number of constraints. Followed by Control Environment, Risk Assessment, Information and Communication, and Monitoring Activity. They are organizational structure constraints concerning rights and authority, resources, implementing attitudes and communication. Basically, all obstacles in the internal control of the sales cycle at a distributor company in Manado are interconnected one with another. Where the biggest obstacle faced for each component of COSO's internal control is the resource constraint that greatly influences the management of internal control (to be implemented well), such as lack of awareness in carrying out responsibilities to achieve company goals. Because sales revenue is the heart of a distributor's business, therefore it requires better and clearer regulations for sales transactions, especially the application of internal control in the company.
\end{abstract}

Keywords: COSO Internal Control, Sales Cycle.

Abstrak. Penelitian ini bertujuan menganalisis sistem pengendalian internal siklus penjualan pada perusahaan distributor di Manado dengan menggunakan pengendalian internal COSO. Penelitian ini adalah penelitian kualitatif dengan pendekatan eksploratori. Data diperoleh melalui teknik wawancara mendalam, observasi dan studi dokumentasi. Hasil penelitian menunjukkan bahwa siklus penjualan pada PT Hasjrat Abadi Cabang Manado dan PT. Bosowa Group Manado sudah dilakukan sebagaimana prosedur yang ditetapkan perusahaan, namun masih perlu ditingkatkan prosedur - prosedur pengendalian internal supaya tidak ada lagi penyimpangan dalam proses penjualan kredit di kedua perusahaan yang menjadi objek penelitian tersebut. Pengendalian internal siklus penjualan pada PT. Hasjrat Abadi Cabang Manado dan Bosowa Group telah sesuai dan dilaksanakan berdasarkan pedoman pengendalian internal COSO (The Committee Of Sponsoring Organizations Of Treadway Commission) yang meliputi asas lingkungan pengendalian, analisis risiko, aktivitas pengendalian, informasi dan komunikasi, serta aktivitas pemantauan atau monitoring. Namun, dalam pelaksanaan pengendalian internal pada siklus penjualan sesuai dengan pedoman COSO masih ditemukan beberapa kendala dalam setiap asas tersebut. Aktivitas pengendalian merupakan komponen yang paling banyak memiliki kendala, yang kedua komponen Lingkungan Pengendalian, kemudian komponen Penilaian risiko selanjutnya yang keempat komponen informasi dan komunikasi, dan yang terakhir adalah komponen aktivitas pemantauan. Kendala-kendala tersebut yaitu kendala struktur organisasi menyangkut hak dan wewenang, sumber daya, sikap pelaksana dan komunikasi. Pada dasarnya, semua kendala dalam pengendalian internal siklus penjualan baik pada PT.Hasjrat Abadi maupun PT.Bosowa Group Cabang Manado saling berhubungan satu dengan yang lainnya. Dimana kendala yang paling besar dihadapi untuk setiap komponen pengendalian internal COSO adalah kendala sumber daya yang sangat mempengaruhi pengelolaan pengendalian internal terlaksana dengan baik, seperti kurangnya kesadaran dalam melaksanakan tanggung jawab untuk mencapai tujuan perusahaan. Karena penjualan merupakan jantung berjalannya suatu perusahaan distributor, maka perlu adanya peraturan yang lebih baik dan jelas terhadap suatu transaksi penjualan, terutama adanya penerapan pengendalian internal pada perusahaan.

Kata kunci: Pengendalian Internal COSO, Siklus Penjualan. 


\section{Pendahuluan}

Dalam perusahaan dagang penjualan merupakan pilar utama, karena penjualan merupakan sumber terjadinya pendapatan bagi perusahaan. Pada dasarnya, perusahaan dagang melakukan penjualan secara tunai ataupun secara kredit. Dengan demikian perusahaan memperoleh pendapatan baik secara langsung (tunai) atau tidak langsung (piutang) melalui penjualan yang dilakukan perusahaan tersebut. Meskipun sebenarnya pengusaha lebih menyukai jika transaksi penjualan dilakukan secara tunai, karena pengusaha langsung menerima kas dan kas tersebut bisa digunakan kembali untuk mendatangkan pendapatan selanjutnya. Akan tetapi disisi lain pengusaha tersebut tetap juga ingin mencapai tujuan utamanya yaitu melayani dan memuaskan kebutuhan konsumen sehingga penjualan kredit merupakan suatu penyelesaian dari masalah yang dialami oleh pengusaha.Pengendalian intern organisasi perusahaan merupakan salah satu fungsi utama dari sistem informasi akuntansi. Oleh karena itu, sistem informasi akuntansi harus dapat menunjang pengendalian intern yang diterapkan oleh perusahaan, sistem informasi akuntansi akan mencatat seluruh aktivitas perusahaan secara otomatis sehingga pimpinan perusahaan akan memperoleh laporan-laporan yang bermanfaat untuk menilai efisiensi perusahaan, menetapkan kebijakan-kebijakan dan mengambil keputusan. Komponen pengendalian internal menurut Committee of Sponsoring Organization (COSO) adalah lingkungan pengendalian, analisis resiko, aktivitas pengendalian, informasi dan komunikasi, dan monitoring (COSO, 2012).

Penjualan merupakan aktivitas yang sangat penting dalam perusahaan, penjualan merupakan sumber pendapatan bagi perusahaan. Tujuan perusahaan untuk memperoleh laba yang lebih optimal dari hasil penjualan merupakan unsur terpenting untuk mempertahankan kelangsungan hidup suatu perusahaan. Masalahnya adalah bagaimana agar pengendalian intern penjualan dapat berfungsi dengan efektif, untuk mengatasinya diperlukan sistem pengendalian internal yang memadai, sehingga dapat membantu management perusahaan menjalankan usahanya. Sistem informasi akuntansi penjualan diperlukan untuk menyediakan bukti pencatatan dan pelaporan yang memadai atas seluruh kegiatan penjualan perusahaan, sehingga dapat dijadikan informasi yang berguna bagi kepentingan management dalam pengambilan keputusan.

Untuk wilayah Sulawesi Utara, PT. Hasjrat Abadi tidak hanya menjadi distributor kendaraan Toyota dan Yamaha tetapi juga menjadi distributor Spareparts, Seng, Semen, Cat, Yanmar, Generator dan sebagainya yang biasanya disebut sebagai barang dagang umum. Transaksi penjualan pada PT Hasjrat Abadi dilakukan secara tunai maupun kredit, setiap transaksi penjualan kredit pasti menimbulkan piutang. Adapun piutang pada PT. Hasjrat Abadi digolongkan dalam bagian yaitu Piutang Dagang, Piutang Afiliasi dan Piutang Leasing.

Piutang dagang yang dimaksud dalam transaksi piutang di PT. Hasjrat Abadi adalah transaksi penjualan kredit yang terjadi untuk penjualan barang dagang umum yang dijual di PT. Hasjrat Abadi kepada subdealer/Toko dengan Payment of term serta batasan nominal kredit yang telah disepakati sesuai dengan ketentuan dan kebijakan perusahaan. Piutang dagang afiliasi adalah transaksi antar anak perusahaan dibawah management PT. Hasjrat Abadi yang dilunasi setiap akhir bulan sesuai dengan Rekonsiliasi antar Cabang maupun rekonsiliasi antar kantor yang terjadi di PT. Hasjrat Abadi dan anak perusahaannya. Sedangkan untuk piutang Leasing adalah transaksi penjualan kredit dengan kerjasama pihak ketiga atau perusahaan pembiayaan guna membiayai pembelian unit kendaraan bermotor baik mobil maupun motor dengan ketentuan pembayaran 7 hari setelah tanggal transaksi sesuai dengan kesepakatan yang berlaku antara pihak PT. Hasjrat Abadi sebagai main dealer Resmi kendaraan Toyota dan Yamaha di wilayah Sulawesi, Maluku dan Nusa Tenggara dengan perusahaan pembiayaan.

Dalam penjualan kredit per 31 Desember 2016, dicatat bahwa total Piutang bermasalah atau sudah diatas 120 hari dari tanggal jatuh tempo adalah sebesar Rp. 1.836.533.454,-. Total piutang menunggak di PT. Hasjrat Abadi tersebut dapat dikategorikan tidak stabil hal ini dikarenakan piutang yang menjadi perhatian karena sudah dikategorikan macet dari tahun ke tahun selalu naik turun. Di tahun 2015 dari data yang diperoleh diketahui bahwa piutang macet di PT. Hasjrat Abadi mencapai Rp 3.104.333.291,-. Data piutang dagang berdasarkan transaksi penjualan kredit periode tahun 2014- 2016 ditunjukkan sesuai tabel. 1.1. 
Tabel. 1.1 Rincian Piutang Menunggak PT. Hasjrat Abadi Cab. Manado

\begin{tabular}{|l|r|r|r|}
\hline \multicolumn{1}{|c|}{ Keterangan } & \multicolumn{1}{c|}{$\mathbf{2 0 1 4}$} & \multicolumn{1}{c|}{$\mathbf{2 0 1 5}$} & \multicolumn{1}{c|}{$\mathbf{2 0 1 6}$} \\
\hline Lancar (1-30 hari) & $37,641,361,866$ & $32,603,227,403$ & $33,119,042,683$ \\
\hline Dalam Perhatian Khusus (31-60 hari) & $12,232,312,023$ & $15,898,132,947$ & $9,965,656,359$ \\
\hline Kurang Lancar (61-90 hari) & $2,584,431,437$ & $15,361,044,415$ & $91,965,649$ \\
\hline Diragukan (91-120 hari) & $424,459,324$ & $10,473,066,312$ & $6,570,228$ \\
\hline Macet (> 120 hari) & $1,336,389,869$ & $3,104,333,291$ & $1,836,533,454$ \\
\hline Total & $\mathbf{5 4 , 2 1 8 , 9 5 4 , 5 1 9}$ & $\mathbf{7 7 , 4 3 9 , 8 0 4 , 3 6 8}$ & $\mathbf{4 5 , 0 1 9 , 7 6 8 , 3 7 3}$ \\
\hline
\end{tabular}

Sumber : Laporan Daftar Umur Piutang PT. Hasjrat Abadi setelah closing Tahun 2014 - 2016

Tabel 1.1 diatas merupakan nominal piutang tak tertagih terjadi pada transaksi piutang dagang atau transaksi langsung dengan subdealer / toko atau terhadap penjualan barang dagang umum seperti spareparts, seng, semen, cat, ban mobil, ban motor, dan sebagainya. Kendala yang paling sering terjadi adalah pelunasan piutang sudah diatas tanggal jatuh tempo, pemberian kredit kembali kepada pelanggan yang masih memiliki saldo piutang yang telah jatuh tempo, bahkan sering adanya dokumen yang kurang valid yang digunakan pihak yang memohon kredit sehingga mengakibatkan adanya kendala terhadap penagihan, manipulasi data customer dengan memanfaatkan kemudahan pemberian kredit, bahkan ada yang sampai menggunakan nama orang lain sehingga merugikan berbagai pihak. Hal ini dilakukan dalam mempercepat tercapainya target penjualan sebagai tanggung jawab pihak marketing (Donald Porajow, dalam hasil wawancara)

Selanjutnya, Bosowa merupakan sebuah perusahaan swasta nasional yang didirikan pada tahun 1973 di Makassar, Sulawesi Selatan. Nama Bosowa berasal dari nama 3 Kerajaan Bugis yaitu Bone, Soppeng dan Wajo. Bosowa bergerak di 6 grup usaha yaitu otomotif, semen, pertambangan dan energi, jasa keuangan, properti dan pendidikan. Selain menjalankan grup usaha intinya, Bosowa juga menjalankan sejumlah proyek perintis di bidang media, olahraga dan agrokultur. Bosowa juga melakukan kegiatan CSR di bidang pendidikan, kemanusiaan dan keagamaan, serta sosial dan kebudayaan.

Menyadari potensi pasar dan kebutuhan masyarakat akan sistem transportasi yang terintegrasi, Bosowa Otomotif juga merambah ke bidang penyediaan jasa transportasi. Grup Otomotif merupakan cikal bakal usaha Bosowa serta ekspansi bisnis Bosowa. Berawal dari distributor mobil Jepang Datsun pada tahun 1978, grup usaha Bosowa Otomotif terus berkembang, sehingga saat ini menjadi distributor eksklusif untuk Mitsubishi. Pengalaman lebih dari 40 tahun membuat Bosowa Otomotif menjadi pemimpin pasar di kawasan Indonesia Timur. Hasil survey pendahuluan pada PT Bosowa Group untuk transaki penjualan barang dagang umum seperti semen dan spareparts diperoleh data sesuai Tabel 1.2.

Tabel.1.2 Rincian Piutang PT. Bosowa Group Cabang Manado

\begin{tabular}{|l|c|c|c|}
\hline \multicolumn{1}{|c|}{ Keterangan } & 2014 & 2015 & 2016 \\
\hline 2) 0 30 days (Lancar) & $1,382,891,665$ & $1,327,229,438$ & $574,092,164$ \\
\hline 3) 31 60 days (Dalam Perhatian Khusus) & $719,983,563$ & $1,000,464,101$ & $2,062,500$ \\
\hline 4) 61 90 days (Kurang Lancar) & $198,432,809$ & $938,958,664$ & $53,875,781$ \\
\hline 5) 91 120 days (Meragukan) & $31,864,550$ & $206,901,925$ & $4,657,772$ \\
\hline 6) Over 120 days (Macet) & $170,987,565$ & $87,091,377$ & $1,375,670,404$ \\
\hline T o t a 1 & $2,504,160,152$ & $3,560,645,506$ & $2,010,358,621$ \\
\hline
\end{tabular}

Sumber : Laporan Daftar Umur Piutang PT. Bosowa Group Tahun 2014 -2016

Penjualan kredit di PT. Bosowa Group sesuai Tabel 1.2 juga mengalami masalah dalam penagihan piutangnya, bahkan kenaikan yang signifikan terjadi dari tahun 2015 ke tahun 2016 dimana piutang macet atau tidak tertagih mencapai Rp. 1.375.670.404,- hasil piutang tersebut diambil dari data piutang penjualan semen dan spareparts karena Bosowa Group sendiri merupakan perusahaan distributor untuk ke dua product bermerk Bosowa tersebut yang secara detail diperoleh penjualan spareparts paling banyak mengalami kredit macet dibandingkan semen. 
Kelancaran dalam pengembalian piutang usaha terhadap kas sangat berpengaruh besar dalam efektifitas kegiatan operasional perusahaan. Semakin cepat piutang usaha dapat ditagih, maka kegiatan operasional perusahaan akan semakin lancar. Dalam menghadapi permasalahan dan kecurangan pada bagian piutang maupun penjualan, sebuah perusahaan membutuhkan alat bantu yang efektif dan efisien. Pada perusahaan menengah keatas, seorang manajer tidak setiap saat dapat mengontrol langsung kinerja karyawannya. Sebagai pengganti kehadiran manajer, manajemen harus mendelegasikan sebagian wewenangnya dan mengandalkan pada prosedur-prosedur pengendalian internal seperti lingkungan pengendalian, analisis resiko, aktivitas pengendalian, informasi dan komunikasi serta monitoring.

Tujuan penelitian ini adalah menganalisis pengendalian internal yang dilakukan pada siklus penjualan sesuai dengan komponen dalam COSO yaitu lingkungan pengendalian, analisis risiko, aktivitas pengendalian, informasi dan komunikasi serta monitoring, faktor-faktor yang menjadi masalah dalam pengendalian internal pada siklus penjualan, dan upaya pencegahan yang dilakukan dalam pengendalian internal siklus penjualan pada PT. Hasjrat Abadi Cabang Manado dan PT. Bosowa Cabang Manado.

\section{Model Analisis}

Model analisis pada penelitian ini dimulai dengan telaah paradigma melalui kajian isu-isu empirik tentang penyebab piutang tidak tertagih dalam siklus penjualan pada perusahaan distributor di Manado, yaitu PT. Hasjrat Abadi Cabang Manado dan PT. Bosowa Group Cabang Manado yang didukung dengan wawancara (in-depth interviews), studi dokumentasi, dan observasi. Selanjutnya adalah tahapan pengumpulan data, pengolahan data, periksa keabsahan data dan penyusunan laporan penelitian. Berikut gambar model analisis yang dilakukan.

\section{Gambar 1. Model Analisis}

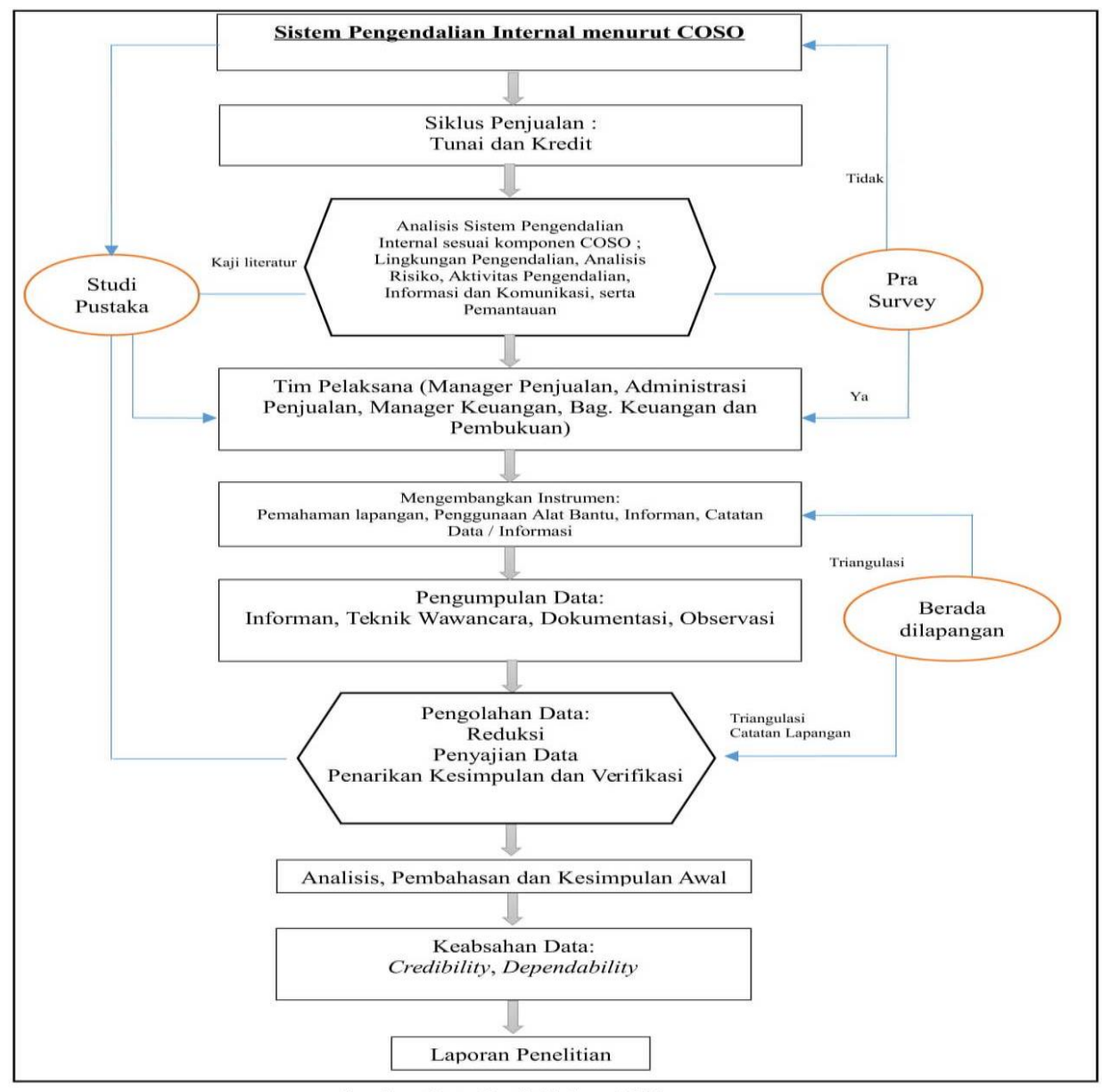

Sumber: Data Hasil Olahan, 2018 


\section{Metode Penelitian}

Penelitian ini menggunakan metode penelitian kualitatif dengan pendekatan eksploratori (exploratory approach). Kirk dan Miller dalam Moleong (2010:4) mendefinisikan metode kualitatif sebagai suatu tradisi dalam ilmu pengetahuan yang bergantung pada pengamatan seseorang. Pengamatan tersebut berhubungan dengan orang-orang tersebut dalam bahasanya dan peristilahannya. Metode penelitian kualitatif dengan pendekatan eksploratori dipilih oleh peneliti untuk mendapatkan informasi yang lebih lengkap, mendalam sampai pada titik jenuh dimana informasi-informasi yang didapatkan memiliki kesamaan maksud dan/atau makna, kredibel dan bermakna dengan melakukan wawancara kepada individu yang terlibat dalam aktivitas dan proses pengendalian internal siklus penjualan pada perusahaan. Sumber data yang digunakan dalam penelitian ini yaitu: 1) Data primer yaitu semua data yang didapat langsung dari sumber data yang diteliti. Sumber data ini diperoleh melalui wawancara mendalam yang dilakukan kepada informan kunci yaitu manager penjualan, bagian administrasi penjualan dan pihak yang terkait dengan transaksi penjualan pada perusahaan. 2 2) Data sekunder adalah data yang diperoleh dari teknik pengumpulan data yang menunjang data primer. Data sekunder yang sudah diperoleh adalah daftar umur piutang di PT. Hasjrat Abadi Cab. Manado dan PT. Bosowa Cabang Manado, SOP Penjualan dan Pemberian Kredit Pelanggan. Teknik pengumpulan data yang dilakukan dalam penelitian ini adalah wawancara, studi dokumentasi dan observasi atau gabungan ketiganya yang disebut triangulasi. Informan dalam penelitian adalah orang atau pelaku yang benar benar tahu dan menguasai masalah, serta terlibat langsung dengan masalah penelitian. Pemilihan informan sebagai sumber data dalam penelitian ini adalah berdasarkan pada asas subyek yang menguasai permasalahan, memiliki data, dan bersedia memberikan informasi lengkap dan akurat. Penentuan informan dalam penelitian ini menggunakan metode purposive. Informan yang dipilih sesuai dengan kriteria yang relevan dengan masalah pengendalian internal pada siklus penjualan. Kunci dasar penggunaan prosedur ini adalah penguasaan informasi dari informan dan secara logika menguasai informasi yang terjadi di dalam proses tindak lanjut (Bungin, 2007).

Teknik analisis data yang digunakan dalam penelitian ini adalah model analisis interaktif Miles and Huberman (1994:16) yang menyebutkan bahwa "Aktivitas dalam analisis data kualitatif dilakukan secara interaktif dan berlangsung secara terus menerus sampai tuntas, sehingga datanya jenuh". Dalam penelitian Teknik analisis data yang digunakan adalah 1) Content Analysis (Analisis Isi); 2) Reduksi Data; 3) Penyajian Data; 4) Penarikan Kesimpulan. Uji keabsahan data yang digunakan dalam penelitian ini meliputi uji validitas internal (credibility) dengan memanfaatkan triangulasi yang terdiri dari triangulasi sumber dan triangulasi teknik dan uji reliabilitas (dependability) yang dilakukan oleh pembimbing mulai dari memeriksa keseluruhan aktifitas penelitian, mulai dari menentukan masalah/ fokus, menentukan sumber data, menentukan analisis data, melakukan uji keabsahan data dan sampai pada pembuatan kesimpulan/ laporan akhir.

\section{Analisis Pembahasan}

Penelitian ini telah dilaksanakan pada bulan Agustus sampai dengan Desember 2017, dilakukan pendalaman di dua perusahaan yang dalam hal ini memiliki kesamaan dalam transaksinya yaitu sebagai dealer dan distributor, pada awal mula penelitian ini dilakukan hanya menggunakan satu objek penelitian yaitu PT. Hasjrat Abadi, namun pada berjalannya penelitian maka dipilihlah PT. Bosowa Berlian Motor untuk dijadikan pembanding dalam pelaksanaan sistem informasi akuntansi siklus penjualan berdasarkan pengendalian internal COSO yaitu untuk menilai komponen lingkungan pengendalian, penilaian risiko, aktivitas pengendalian, informasi dan komunikasi dan sampai pada aktivitas pemantauan untuk memenuhi tujuan perusahaan itu sendiri.

Pengumpulan data dilakukan dengan cara wawancara mendalam (in-depth interview) berdasarkan metode purposive sampling yaitu sampel yang dipilih berdasarkan pertimbanganpertimbangan tertentu menyesuaikan tujuan penelitian, serta menggunakan alat perekam untuk membantu pengumpulan data secara akurat dan sebagai alat bantu untuk membuat transkrip wawancara, serta dokumen-dokumen pendukung penelitian seperti daftar umur piutang, informasi document penjualan, laporan hasil penjualan dan dokumentasi sistem yang digunakan untuk transaksi penjualan pada PT. Hasjrat Abadi, PT. Bosowa Berlian Motor dan Bosowa Semen. Dalam penelitian ini memiliki 8 orang informan yang sudah memenuhi kriteria untuk menjadi informan sebagaimana yang telah dibahas di bab sebelumnya. Adapun diantaranya terdapat 5 informan yang menjadi key informant yang 
akuntabel serta mampu untuk memberikan informasi sesuai data yang menjadi fokus penelitian ini. Informan tidak dilihat dari jumlahnya tetapi tergantung dari kelengkapan dan kedalaman data yang dapat dikumpulkan oleh peneliti.

Data yang terkumpul kemudian diolah, dibuat transkrip data, kemudian dianalisis menggunakan analisis isi (content analysis), diberi kode, dan dikategorikan kedalam tema. Data tersebut disandingkan, dilakukan triangulasi antara sumber data dengan data lainnya sehingga didapat kesimpulan akhir, serta saran dari peneliti.

Penjualan pada PT. Hasjrat Abadi dan PT. Bosowa Group Cabang Manado merupakan pilar utama mencapai tujuan perusahaan, sebagai perusahaan distributor yang memonopoli penjualan spareparts dengan merk Toyota dan Mitsubishi menjadikan kedua perusahaan ini memiliki total penjualan yang sangat besar. Untuk PT. Hasjrat Abadi sendiri, selain memiliki spareparts, juga memiliki seng, semen, cat, ban, dan sebagainya sebagai barang dagang umum. Sehingga dapat dikatakan menjadi perusahaan distributor multi product. Sedangkan, PT. Bosowa Cabang Manado terbagi dua, yaitu PT. Bosowa Berlian Motor sebagai distributor spareparts dan PT. Bosowa Semen sebagai distributor Semen Merk Bosowa.

Siklus penjualan kedua perusahaan ini dari hasil penelitian yang diperoleh, dimulai dari menerima transaksi/nota pesanan barang dari toko/subdealer, maupun pelanggan perorangan, selanjutnya dilakukan penginputan data pelanggan ke sistem yang dimiliki perusahaan, untuk PT. Hasjrat Abadi Manado dan Bosowa Group Cabang Manado menggunakan sistem yang sama yaitu Dealer Management System (DMS), setelah data master customer dibuat, kemudian akan dilanjutkan dengan pembuatan purchase order (PO) secara sistem, PO tersebut kemudian di verifikasi oleh manager penjualan dan pimpinan perusahaan, setelah diverifikasi, bagian accounting akan melakukan approval/konfirmasi data master yang sudah dibuat oleh wiraniaga untuk bisa melanjutkan ke pembayaran.

Selanjutnya, wiraniaga akan mengarahkan pelanggan ke kasir untuk melakukan pembayaran, pada saat pembayaran customer akan menerima kwitansi pembayaran atas transaksi yang telah dilakukan. Kemudian proses akan dilanjutkan oleh bagian administrasi sales untuk dilanjutkan ke proses Sales Order (SO) yaitu pembuatan order pembelian untuk memotong stock secara sistem, apabila SO sudah terbit, maka akan diverifikasi kembali oleh manager penjualan dan pimpinan perusahaan. Transaksi yang sudah dilakukan akan di verifikasi kembali oleh bagian pembukuan untuk mencocokkan total penjualan pada SO (sales order) yang sudah terbit dengan kwitansi pembayaran, proses ini dinamakan rekonsiliasi. Dengan adanya verifikasi dari bagian accounting secara otomatis bagian administrasi sales sudah bisa langsung melanjutkan ke penerbitan Delivery Order (DO), faktur pajak dan faktur penjualan. Untuk Faktur Penjualan akan diserahkan ke pelanggan sebagai bukti transaksi, faktur pajak akan diserahkan ke bagian pajak, dan DO akan dibawa ke bagian gudang untuk pengambilan barang.

\section{Analisis Kesesuaian Siklus Penjualan dari Segi Pengendalian Internal COSO komponen Lingkungan Pengendalian, Masalah dan Upaya yang dilakukan.}

Penelitian ini menganalisis bagaimana siklus penjualan di PT. Hasjrat Abadi Cabang Manado dan PT Bosowa Berlian Motor serta PT. Bosowa Semen apakah sudah sesuai dengan Pengendalian Internal versi COSO dalam komponen lingkungan pengendalian, apa masalah yang terjadi dalam lingkup lingkungan pengendalian serta upaya apa saja yang telah dilakukan perusahaan untuk mampu mengatasi masalah-masalah terkait komponen lingkungan pengendalian. Lingkungan pengendalian menciptakan suasana pengendalian dalam suatu organisasi dan mempengaruhi kesadaran personal organisasi tentang pengendalian. Lingkungan pengendalian merupakan landasan untuk semua komponen pengendalian internal yang membentuk disiplin dan struktur. Berdasarkan rumusan COSO, bahwa lingkungan pengendalian didefinisikan sebagai seperangkat standar, proses, dan struktur yang memberikan dasar untuk melaksanakan pengendalian internal di seluruh organisasi.

Dalam hasil wawancara terkait pengendalian internal siklus penjualan sesuai komponen lingkungan pengendalian pada PT. Hasjrat Abadi Cabang Manado dan PT. Bosowa, perusahaan telah membuat kebijakan-kebijakan tertulis mengenai kedisiplinan dan kejujuran yang ditetapkan oleh perusahaan. Kedisiplinan dari segi absensi dan kepatuhan dalam mengerjakan tanggung jawab sesuai 
dengan job description masing-masing, serta menjunjung tinggi etos kerja kejujuran dan siap bertanggung jawab.

Masalah-masalah paling sering terjadi dalam lingkungan pengendalian adalah masalah dalam organisasi itu sendiri, tentang bagaimana meyakinkan individu untuk bertanggung jawab atas tugasnya untuk mencapai tujuan perusahaan. Kurangnya SDM yang kompeten untuk mencapai target yang diharapkan manajemen juga menjadi salah satu masalah yang terjadi dalam lingkup lingkungan pengendalian. Sering juga terjadi masalah karena sales yang keluar masuk, penempatan karyawan yang tidak sesuai kebutuhan, serta belum adanya sanksi yang tegas dari manajemen apabila ada yang bekerja tidak sungguh-sungguh dan tidak bertanggung jawab.

Adapun upaya yang dilakukan dalam mengatasi masalah-masalah yang sering terjadi dalam komponen pengendalian internal lingkungan pengendalian yaitu menempatkan karyawan harus sesuai dengan kebutuhan, dilihat juga risikonya dari awal sebelum penempatan karyawan tersebut, dilakukan proses uji coba dan pembinaan agar mampu bekerja dengan penuh tanggung jawab sehingga apa yang menjadi harapan manajemen sebagai tujuan dapat tercapai.

\section{Analisis Kesesuaian Siklus Penjualan dari Segi Pengendalian Internal COSO komponen Analisis Risiko, Masalah dan Upaya yang dilakukan.}

Dalam menganalisis kesesuaian siklus penjualan dari segi pengendalian internal COSO komponen analisis risiko, ditemukan 3 (tiga) tema yaitu: penilaian risiko, masalah dalam penilaian risiko dan upaya untuk mengatasi masalah penilaian risiko. Menurut COSO, penilaian risiko melibatkan proses yang dinamis dan interaktif untuk mengidentifikasi dan menilai risiko terhadap pencapaian tujuan. Risiko itu sendiri dipahami sebagai suatu kemungkinan bahwa suatu peristiwa akan terjadi dan mempengaruhi pencapaian tujuan entitas, dan risiko terhadap pencapaian seluruh tujuan dari entitas ini dianggap relatif terhadap toleransi risiko yang ditetapkan. Oleh karena itu, penilaian risiko membentuk dasar untuk menentukan bagaimana risiko harus dikelola oleh organisasi.

Hasil wawancara terkait pengendalian internal siklus penjualan sesuai komponen analisis risiko pada PT. Hasjrat Abadi Cabang Manado dan PT. Bosowa yang menjadi objek penelitian, perusahaan telah menetapkan tujuan dengan kejelasan yang cukup untuk memungkinkan identifikasi dan penilaian risiko yang berkaitan dengan tujuan. Risiko ditetapkan sebagai bagian dari pelaksanaan pengendalian internal, misalnya, dalam target yang $75 \%$ adalah penjualan kredit, otomatis sudah harus dipikirkan nantinya bagaimana supaya tidak terjadi kredit macet. Jadi sudah teridentifikasi dari awal.

Pada dasarnya isu tentang pengendalian internal dilatarbelakangi oleh masalah keagenan. Permasalahan keagenan muncul karena pengelolaan perusahaan yang terpisah dengan pemiliknya. Pemilik (principal) sebagai pemasok modal perusahaan mendelegasikan wewenangnya atas pengelolaan perusahaannya kepada manajer profesional (agent) sehingga kewenangan untuk menggunakan sumber daya perusahaan ada pada tangan manajer (Jensen and Meckling,1976 dalam Fitriyani,dkk,2015).

Pengendalian internal dalam komponen penilaian risiko juga memiliki berbagai keterbatasan seperti penyimpangan prosedur penjualan kredit, tidak sesuai dengan aturan-aturan sehingga menyebabkan timbulnya piutang bahkan sampai kredit macet. Penilaian risiko membentuk dasar untuk menentukan bagaimana risiko harus dikelola organisasi, berbagai upaya dilakukan management untuk meminimalisir terjadinya masalah yang dapat menghambat tujuan perusahaan salah satunya dengan mengoptimalkan pengendalian internal pada komponen penilaian risiko ini.

Upaya untuk melakukan pembebanan ke sales yang melakukan penjualan tidak sesuai prosedur sehingga menyebabkan piutang yang tidak tertagih. Menggunakan pihak ketiga untuk menangani risiko piutang tidak tertagih dalam jumlah besar dan menyatakan blacklist pada system yang digunakan perusahaan supaya tidak ada lagi transaksi pada toko tersebut dan memberikan sanksi kepada sales yang melakukan penjualan tersebut. 


\section{Analisis Kesesuaian Siklus Penjualan dari Segi Pengendalian Internal COSO komponen Aktivitas Pengendalian, Masalah dan Upaya yang dilakukan.}

Kesesuaian komponen ketiga dalam pengendalian internal COSO yaitu aktivitas pengendalian. Menurut COSO, aktivitas pengendalian adalah tindakan-tindakan yang ditetapkan melalui kebijakankebijakan dan prosedur-prosedur yang membantu memastikan bahwa arahan manajemen untuk mengurangi risiko terhadap pencapaian tujuan dilakukan. Aktivitas pengendalian dilakukan pada semua tingkat entitas, pada berbagai tahap dalam proses bisnis, dan atas lingkungan teknologi.

Terkait pengendalian internal siklus penjualan sesuai komponen aktivitas pengendalian pada PT. Hasjrat Abadi Cabang Manado dan PT. Bosowa yang menjadi objek penelitian, perusahaan memilih dan mengembangkan aktivitas pengendalian yang berkontribusi terhadap mitigasi risiko pencapaian sasaran pada tahap yang dapat diterima seperti dokumen-dokumen penjualan, bukti serah terima barang yang jelas, kuantitas yang diberikan sesuai dengan pesanan, system yang terstandarisasi sehingga menghasilkan suatu siklus penjualan (input dan output) yang sesuai dengan yang diharapkan manajemen. Perusahaan kemudian memilih dan mengembangkan aktivitas pengendalian umum atas teknologi untuk mendukung tercapainya tujuan, hal ini dengan melakukan pengecekan independen untuk menguji kesesuaian jumlah stock yang tercatat pada sisten dengan actual pada gudang penyimpanan secara rutin. Aktivitas pngendalian melalui kebijakan-kebijakan yang menetapkan apa yang diharapkan dan prosedur-prosedur yang menempatkan kebijakan kedalam tindakan sehingga seluruh transaksi penjualan sudah dilakukan sesuai dengan aturan dan kebijakan yang berlaku.

Aktivitas pengendalian berdasarkan komponen COSO merupakan yang paling banyak memiliki penyimpangan dalam pelaksanaannya, hal ini karena dalam aktivitas pengendalian berkaitan langsung dengan kegiatan operasional perusahaan seperti penjualan, target dan sasaran untuk keberhasilan perusahaan. Sehingga kendala-kendala yang terjadi seperti gudang penyimpanan yang belum layak serta tidak didukung sistem keamanan yang layak, SDM yang ditempatkan tidak melaksanakan tugas sesuai SOP sehingga barang yang keluar dari gudang tidak sama dengan pesanan/purchase order, kesalahan pengiriman barang tidak sesuai order, sehingga menyebabkan keterlambatan penagihan dan berdampak ke masalah penagihan piutang. Penyalahgunaan sistem penjualan, manipulasi data penjualan bahkan sampai pada fiktif order, bahkan banyaknya selisih kurang pada stock digudang penyimpanan setiap kali dilakukan pemeriksaan, SDM yang tidak memiliki kesadaran terhadap tanggung jawab yang diemban menjadi salah satu faktor pemicu banyaknya terjadi penyimpangan pada pengendalian internal komponen aktivitas pengendalian ini.

Adapun banyak hal yang menjadi kendala tersebut selalu diupayakan untuk tidak terjadi terus menerus, upaya yang dilakukan adalah pembatasan order untuk transaksi toko langganan, sesuai dengan credit limit dan term of payment yang sudah disetujui oleh manajemen, pemberian somasi dan penagihan dengan pihak ketiga untuk piutang yang sudah tidak tertagih dalam jumlah besar. Pemberian sanksi tegas seperti dilakukan proses polisi untuk sales yang sengaja melakukan penyimpangan penjualan dan pemeriksaan stock secara rutin di gudang dalam kurun waktu 6 bulan sekali.

\section{Analisis Kesesuaian Siklus Penjualan dari Segi Pengendalian Internal COSO komponen Informasi dan Komunikasi, Masalah dan Upaya yang dilakukan.}

COSO menjelaskan bahwa informasi sangat penting bagi setiap entitas untuk melaksanakan tanggung jawab pengendalian internal guna mendukung pencapaian tujuan-tujuannya. Informasi yang diperlukan manajemen adalah informasi yang relevan dan berkualitas baik yang berasal dari sumber internal maupun eksternal dan informasi yang digunakan untuk mendukung fungsi komponenkomponen lain pengendalian internal. Informasi diperoleh ataupun dihasilkan melalui proses komunikasi antar pihak internal maupun eksternal yang dilakukan secara terus-menerus, berulang, dan berbagi.

Hasil penelitian bahwa otorisasi transaksi oleh pihak-pihak yang berwenang untuk menghasilkan informasi transaksi yang berkualitas dan relevan guna mendukung fungsi sistem pengendalian internal. Prosedur yang dilakukan untuk suatu transaksi memberikan keyakinan bahwa informasi yang disajikan dari sistem telah relevan, ditangkap, diproses, dan dilaporkan sistem secara actual dan real time. 
Beberapa hal yang menjadi kendala dalam informasi dan komunikasi biasanya dimulai dari jaringan sistem informasi dan komunikasi yang kurang memadai sehingga transaksi yang terinput tidak up-to-date yang menyebabkan tidak mampu menyajikan data secara real time. Proses penjualan yang menjadi terganggu karena kurangnya efisiensi waktu untuk melakukan transaksi manual. Komunikasi pun menjadi kurang lancar dan manajemen menjadi kesulitan untuk menerima informasi atau laporan secara real time guna menjadi bahan evaluasi untuk mencapai tujuan. Ada juga karena proses transaksi secara keseluruhan sudah sangat mengandalkan sistem tetapi karena adanya masalah pada jaringan sehingga mempengaruhi sinkronisasi data dari user marketing ke system accounting and finance karena data yang diterima oleh bagian analis sudah tidak valid/belum up-to-date.

Adapun hal-hal yang menjadi upaya yang dilakukan yaitu peningkatan sarana dan prasarana jaringan komunikasi untuk mendukung pengoperasian sistem sehingga transaksi yang diinput dapat disajikan secara tepat waktu guna menunjang pencapaian tujuan perusahaan, serta adanya kebijakan untuk tidak menyalahgunakan wewenang penggunaan user dalam bertransaksi ataupun operasional perusahaan sehingga tidak terjadi kecurangan.

\section{Analisis Kesesuaian Siklus Penjualan dari Segi Pengendalian Internal COSO Monitoring, Masalah dan Upaya yang dilakukan.}

Aktivitas pemantauan menurut COSO merupakan kegiatan evaluasi dengan beberapa bentuk apakah yang sifatnya berkelanjutan, terpisah maupun kombinasi keduanya yang digunakan untuk memastikan apakah masing-masing dari kelima komponen pengendalian internal mempengaruhi fungsi - fungsi dalam setiap komponen, ada dan berfungsi. Secara singkat dapat dikatakan bahwa pemantauan dilakukan untuk memberikan keyakinan apakah pengendalian internal telah dilakukan secara memadai atau tidak. Dari hasil pemantauan tersebut dapat ditemukan kelemahan dan kekurangan pengendalian sehingga dapat diusulkan pengendalian yang lebih baik.

Aktivitas pemantauan atau monitoring tak luput dari salah satu komponen penting COSO untuk menganalisis siklus penjualan dari segi pengendalian internal pada PT.Hasjrat Abadi dan PT. Bosowa Group yang merupakan perusahaan monopoli di kota Manado. Monitoring telah dilakukan oleh orang yang independen baik pada tahap desain maupun pengoperasian pengendalian pada waktu yang tepat guna menentukan operasional perusahaan berjalan sebagaimana yang diharapkan. Inspeksi mendadak yang dilakukan pimpinan untuk memastikan seluruh aktivitas perusahaan beroperasi sebagaimana yang diharapkan dan menetukan pengendalian internal telah disesuaikan dengan perubahan keadaan yang selalu dinamis.

Komponen aktivitas pemantauan ini juga memiliki beberapa kendala, hal ini dikarenakan aktivitas pemantauan merupakan alat pengukur berhasil tidaknya pelaksanaan pengendalian internal dilakukan dalam suatu perusahaan, setiap evalusai yang dilakukan akan terus dikembangkan sehingga mencapai tujuan perusahaan. Pertemuan atau forum diskusi rutin seperti rapat kerja yang dilakukan sesuai periode atau jadwal yang ditetapkan manajemen untuk menyajikan laporan aktivitas perusahaan baik transaksi penjualan maupun aktivitas lainnya, serta mengetahui masalah-masalah yang terjadi dilapangan dan menyesuaikan terhadap perubahan keadaan yang berkesinambungan.

Kebijakan yang dilakukan manajemen sebagai bentuk tindakan untuk mengontrol aktivitas penjualan sehingga mencegah terjadinya kecurangan, dan memberi keyakinan bahwa pengendalian internal perusahaan sudah berjalan dengan baik serta dapat ditemukan kelemahan dan kekurangan pengendalian sehingga dapat diusulkan pengendalian yang lebih baik.

\section{Penutup}

Kesimpulan dalam penelitian ini adalah: transaksi penjualan sudah dilakukan sebagaimana prosedur yang ditetapkan perusahaan, namun masih perlu ditingkatkan prosedur-prosedur pengendalian internal supaya tidak ada lagi penyimpangan dalam proses penjualan kredit di kedua perusahaan yang menjadi objek penelitian. Kesesuaian pengendalian internal COSO (The Committee Of Sponsoring Organizations Of Treadway Commission) yang meliputi asas lingkungan pengendalian, analisis risiko, aktivitas pengendalian, informasi dan komunikasi, serta aktivitas pemantauan atau monitoring dengan siklus penjualan sudah sesuai. Namun, dalam pelaksanaan pengendalian internal masih ditemukan 
beberapa kendala dalam setiap komponen tersebut. Aktivitas pengendalian merupakan komponen yang paling banyak memiliki kendala, yang kedua komponen lingkungan pengendalian, kemudian komponen penilaian risiko selanjutnya yang keempat komponen informasi dan komunikasi, dan yang terakhir adalah komponen aktivitas pemantauan. Kendala-kendala tersebut yaitu kendala struktur organisasi menyangkut hak dan wewenang, sumber daya, sikap pelaksana dan komunikasi. Pada dasarnya, semua kendala dalam pengendalian internal siklus penjualan pada perusahaan distributor di Manado saling berhubungan satu dengan yang lainnya, dimana kendala yang paling besar dihadapi untuk setiap komponen pengendalian internal COSO adalah kendala sumber daya yang sangat mempengaruhi pengelolaan pengendalian internal terlaksana dengan baik, seperti kurangnya kesadaran dalam melaksanakan tanggung-jawab untuk mencapai tujuan perusahaan. Karena penjualan merupakan jantung berjalannya suatu perusahaan distributor, maka perlu adanya peraturan yang lebih baik dan jelas terhadap suatu transaksi penjualan, terutama adanya penerapan pengendalian internal pada perusahaan.

Saran dalam penelitian ini: 1) Bagi Perusahaan. Pengendalian internal pada siklus penjualan dapat dilakukan secara sistematis dan berkesinambungan yang didukung oleh sumber daya manusia dan teknologi informasi yang memadai sehingga komponen lingkungan pengendalian, analisis risiko, aktivitas pengendalian, informasi dan komunikasi serta monitoring dapat terlaksana dengan baik dan mampu menjadi acuan penilaian pengendalian guna mencapai tujuan perusahaan. Agar pelaksanaan pengendalian internal dapat berjalan efektif, diperlukan proses keikutsertaan semua pihak dalam perusahaan. 2) Bagi Dunia Akademis. Untuk mendapatkan hasil penelitian yang lebih akurat dari penelitian selanjutnya, hal yang bisa dilakukan adalah menambah objek penelitian sebagai pembanding atau menambah key informant, seperti seluruh jajaran management perusahaan, kemudian menambah beberapa key informant pembanding, seperti staff yang bertanggung jawab langsung pada aspek-aspek penilaian yang terkait dengan penjualan.

\section{Daftar Pustaka}

Amat, O., Blake, J., \& Gowthorpe, C. (1995). Management of accounting: The case for an active role. European Management Journal, 13(4), 416-422.

Anthoni, Denda Bedford. (1990). Management Control System, Erlangga, Jakarta.

Azhar Susanto. (2004). Sistem Informasi Manajemen Konsep dan Pengembangannya. Lingga Jaya: Bandung.

Bungin, B. (2007). Penelitian Kualitatif: Komunikasi, Ekonomi, Kebijakan Publik dan Ilmu Sosial Lainnya.

Bushman, R., Chen, Q., Engel, E., \& Smith, A. (2004). Financial accounting information, organizational complexity and corporate governance systems. Journal of Accounting and Economics, 37(2), 167-201.

Chariri, A., \& Ghozali, I. (2007). Teori Akuntansi. Badan Penerbit Universitas Diponegoro: Semarang.

COSO. 2012. Internal Control - Integrated Framework: Executive Summary, Durham, North California, May 2012.

Cron, W. L., \& Sobol, M. G. (1983). The relationship between computerization and performance: a strategy for maximizing the economic benefits of computerization. Information \& management, 6(3), 171-181.

Davis, J.H., Schoorman, F.D., \& Donaldson, L. 1997. Toward a stewardship theory of management. Academy of Management Review, 22: 20-47.

Donaldson, L., \& Davis, J.H. 1989. CEO governance and shareholder returns: Agency theory or stewardship theory. Paper presented at the annual meeting of the Academy of Management, Washington, DC.

Donaldson, L., \& Davis, J. H. 1991. Stewardship theory or agency theory: CEO governance and shareholder returns. Australian Journal of Management,16: 49-64.

Gelinas, U. J., Dull, R. B., \& Wheeler, P. (2011). Accounting information systems. Cengage learning.

Hall, A James. 2013. Accounting Information System. Edisi ke 4, Salemba Empat. Jakarta.

Hartono Jogiyanto. 2014. Metode Penelitian Bisnis Salah Kaprah dan Pengalaman-Pengalama. Edisi Keenam. Cetakan Kedua. Yogyakarta: BFE-Yogyakarta.

IAI, 2004, Standar Akuntansi Keuangan, Jakarta: Salemba Empat.

Ibrahim, 2015. Metodologi Penelitian Kualitatif. Bandung: Penerbit Alfabeta. 
Jensen, M.C and W H,Meckling, "Theory of the Firm: Managerial Behavior, Agency Cost and Ownership Structure", Journal of Financial Economics, Vol. 3, October 1976, Page.305-360.

Janvrin, D. J., Payne, E. A., Byrnes, P., Schneider, G. P., \& Curtis, M. B. (2012). The updated COSO Internal Control-Integrated Framework: Recommendations and opportunities for future research. Journal of Information Systems, 26(2), 189-213.

Subekti, K. V., \& Warsono, S. (2014). Penilaian Kualitas Pengendalian Internal, Kualitas Audit Internal dan Kualitas Komite Audit Berbasis COSO ERM dan PBI pada Perbankan di Indonesia (Doctoral dissertation, Universitas Gadjah Mada).

Kieso, Weygandt dan Kimmel. 2008. Pengantar Akuntansi: Accounting Principle. Edisi Ketujuh. Jakarta

Michalski, G. 2008. Operational Risk in Current Assets Investment Decisions: Portfolio Management Approach in Accounts Receivable (Agro Econ-Czech: Operační Risk v Rozhodování o Běžných Aktivech: Management Portfolia Pohledávek).

Moleong, Lexy J, 2010. Metodologi Penelitian Kualitatif. Bandung: Remaja Rosdakarya.

Mulyadi, 2016, Sistem Akuntansi, Edisi 4, Salemba Empat, Jakarta

Mulyadi, 2014, Auditing 1, Edisi 6, Salemba, Jakarta.

Ngugi, S. K. (2015). Determinants of Accounts Receivables Management in the Hotel Industry in Kenya (Doctoral dissertation).

Rusdi Akbar, 2010. Akuntansi Pengantar, Penerbit: YKPN, Yogyakarta

Santoso, E. B. (2016). Pengaruh Sistem Pengendalian Intern Pemerintah, Pemanfaatan Teknologi Informasi dan Kompetensi Sumber Daya Manusia Terhadap Akuntabilitas Keuangan Daerah (Studi Empiris pada Pemerintah Kabupaten Lampung Timur) The Influence Of Internal Governmental Control System The Use Of Information Technology and Human Resoursces Competence to District Financial Accountability (Empirical Study at East Lampung District) (Doctoral dissertation, Universitas Lampung).

Satori, Djam'an dan Aan Komariah. 2013. Metodologi Penelitian Kualitatif. Bandung: Alfabeta.

Skousen Fred, Stice, Earl K, James D. Stice dan K.. 2004. Akuntansi Intermediate. Edisi Lima Belas, Buku 1. Alih Bahasa oleh Salemba Empat. Jakarta: Salemba Empat.

Skousen, Fred K., Stice, James D., Stice, Earl K., 2009, Akuntansi Keuangan. Jakarta: Salemba Empat.

Sugiyono, 2015. Metodologi Penelitian Kuantitatif, Kualitatif dan Kombinasi (mixed methods). Bandung: Alfabeta.

Sugiyono, 2016. Metodologi Penelitian Kuantitatif, Kualitatif dan Kombinasi (mixed methods). Bandung: Alfabeta.

Warrent, Carl S., James M. Reeve dan Philip E. Fress. 2005. Pengantar Akuntansi. Edisi Dua Puluh Satu, Buku 1. Alih Bahasa oleh Aria Farahmita, Amanugrahani, Taufik Hendrawan, Salemba Empat. Jakarta: Salemba Empat.

Winarno, W. W. (2006). Sistem Informasi Akuntansi. Edisi Kedua. UPP STIM. Yogyakarta.

Zaki, Baridwan. 2011. Intermediate Accounting Edisi 8. Yogyakarta: BPFE. 